\title{
CARLENS ENDOBRONCHIAL CATHETER VERSUS REGULAR ENDOTRACHEAL TUBE DURING THORACIC SURGERY: A COMPARISON OF BLOOD GAS TENSIONS AND PULMONARY SHUNTING
}

\author{
SaIt Tarhan, M.D. and Richard O. Lundborg, M.D."
}

The CARLENS CaTHETER originally was designed to prevent contamination of healthy lungs with secretions during thoracic surgery. Today it is used more often by surgical teams to create a more optimal surgical exposure by excluding the lung in the opened hemithorax from the anaesthetic system. ${ }^{1}$ However, it is known that extremely low arterial oxygen tensions can occur with this technique because of excessive pulmonary shunting through the collapsed lung on the open side of the thorax and atelectatic areas in the dependent lung. ${ }^{2}$

On the other hand, if patients are intubated with a regular endotracheal tube during thoracic surgery, the independent lung could be ventilated at least partially throughout the operation, until the clamping of the bronchus. Theoretically, this would produce less pulmonary shunting in the nondependent lung, with an improved overall effect on oxygenation.

In this study an effort was made to compare these two techniques by measuring the arterial $\mathrm{O}_{2}$ and $\mathrm{CO}_{2}$ tensions, the $\mathrm{pH}$, and the degree of pulmonary shunting in patients undergoing thoracic surgery.

\section{Methods}

Twenty-two patients were studied, 11 of whom were intubated with a Carlens catheter and II with a regular endotracheal tube. In each group, five patients underwent pneumonectomy, four patients lobectomy, and two patients wedge resection. The age range in the Carlens group was 39 to 67 years (average, 54 years) and in the regular endotracheal tube group it was 46 to 74 years (average, 61 years). All patients were premedicated with 6 to $10 \mathrm{mg}$ of morphine, $0.4 \mathrm{mg}$ of atropine, and $100 \mathrm{mg}$ of pentobarbital.

Anaesthesia was induced with 200 to $520 \mathrm{mg}$ of sodium thiopentone. Intubation was carried out after the administration of 60 to $80 \mathrm{mg}$ of succinylcholine. All patients had manually controlled ventilation using a gas flow of 5 liters through a semiclosed system with $\mathrm{CO}_{2}$ absorption. A drip of 0.2 per cent succinylcholine was used intermittently as needed for relaxation. The total dose of succinylcholine, including the amount given for intubation, ranged from 180 to $600 \mathrm{mg}$.

Shortly before induction of anaesthesia and with the patient breathing air, a sample of blood was drawn from the femoral artery. Subsequent samples were obtained as follows from a 16-gauge plastic needle placed in the radial artery: sample 2 was obtained after the anaesthetized patient had been placed in the

-Mayo Clinic and Mayo Foundation: Department of Anesthesiology. 
lateral decubitus position and ventilated with nitrous oxide and oxygen (60:40) and 1 per cent halothane; sample 3 was obtained immediately after the pleural cavity was opened; sample 4 was taken 10 minutes after sample 3 ; sample 5 was taken only from the Carlens group using the same gas mixture, after the lung in the open hemithorax had bcen allowed to collapse; sample 6 was taken from both groups after 10 minutes of ventilation with oxygen and 1 per cent halothane, while the lung on the open side was still collapsed in the Carlens group and while it was fully or partly ventilated in the regular endotracheal group. The amount of expansion in the latter group depended on the surgical manipulation. All samples were drawn before clamping the pulmonary artery. The final sample, sample 7, was taken at the end of the operation with the patient awake, in the supine position, and breathing air.

Appropriate electrodes maintained at $37^{\circ} \mathrm{C}$ were used to determine $\mathrm{PaO}_{2}, \mathrm{PaCO}_{2}$, and $\mathrm{pH}$. Microhaematocrit determinations were also made from each sample. Buffer base values were obtained from the nomogram of Singer and Hastings, ${ }^{3}$ and oxygen saturations were determined by means of an oximeter.

Determinations from sample 6 allowed us to calculate pulmonary shunting.

With the $\mathrm{PaO}_{2}$ values higher than $150 \mathrm{~mm} \mathrm{Hg}$ and the haemoglobin fully saturated, the fractional shunt $\mathrm{Q}_{\mathrm{S}} / \mathrm{Q}_{\mathrm{T}}$ was calculated by means of the following modified shunt cquation:

$$
\frac{\mathrm{Q}_{\mathrm{S}}}{\mathrm{Q}_{\mathrm{T}}}=\frac{0.0031\left(\mathrm{PAO}_{2}-\mathrm{PaO}_{2}\right)}{\mathrm{CaO}_{2}-\mathrm{CV}_{2}+0.0031\left(\mathrm{PAO}_{2}-\mathrm{PaO}_{2}\right)}
$$

With an arterial $\mathrm{O}_{2}$ tension of less than $150 \mathrm{~mm} \mathrm{Hg}$ and the haemoglobin not fully saturated, the following standard shunt equation was used:

$$
\frac{\mathrm{Q}_{\mathrm{S}}}{\mathrm{Q}_{\mathrm{T}}}=\frac{\mathrm{CcO}_{2}-\mathrm{CaO}_{2}}{\mathrm{CCO}_{2}-\mathrm{CvO}_{2}}
$$

in which the pulmonary capillary blood oxygen content is

$$
\mathrm{CCO}_{2}=0.0031 \times \mathrm{PAO}_{2}+\mathrm{SCO}_{2}(1.34 \times \mathrm{Hb})
$$

and the arterial blood oxygen content is

$$
\mathrm{CaO}_{2}=0.0031 \times \mathrm{PaO}_{2}+\mathrm{SaO}_{2}(1.34 \times \mathrm{Hb}) .
$$

Alveolar $\mathrm{O}_{2}$ tensions in both shunt equations were calculated as

$$
\mathrm{PAO}_{2}=\mathrm{PB}-\mathrm{Prr}_{2} \mathrm{O}-\mathrm{PaCO}_{2}-\mathrm{P}_{\text {anaesthetle azent. }}
$$

The arterial-mixed venous oxygen content difference $\left(\mathrm{CaO}_{2}-\mathrm{Cvo}_{2}\right)$ was assumed as 6 volumes $/ 100 \mathrm{ml}^{4}{ }^{4}$

Statistical analyses were accomplished with the Student's $t$ test for unpaired data, with $p=0.05$ as the level of significance.

\section{Results}

After premedication and before induction of anaesthesia, the mean $\mathrm{PaO}_{2}$ was $77 \pm 11 \mathrm{~mm} \mathrm{Hg}$ in the Carlens group (range 70 to $83 \mathrm{~mm} \mathrm{Hg}$ ), while the $\mathrm{PaO}_{2}$ was 
TABLE I

Arterial $\mathrm{O}_{2}$ Tensions During Thoracotomy

\begin{tabular}{|c|c|c|c|c|c|c|}
\hline \multirow{2}{*}{$\begin{array}{l}\text { Arterial } \\
\text { sample* }\end{array}$} & \multirow[b]{2}{*}{$\mathrm{FIo}_{2}$} & \multicolumn{2}{|c|}{$\begin{array}{l}\text { With Carlens catheter: } \\
\qquad \mathrm{PaO}_{2}, \mathrm{~mm} \mathrm{Hg}\end{array}$} & \multicolumn{3}{|c|}{$\begin{array}{l}\text { With regular endotracheal tube: } \\
\qquad \mathrm{PaO}_{2}, \mathrm{~mm} \mathrm{Hg}\end{array}$} \\
\hline & & Mean $\pm \mathrm{SE}$ & Range & Mean $\pm \mathrm{SE}$ & Range & \\
\hline 1 & 0.2 & $77 \pm 11$ & $70-83$ & $67 \pm 1$ & $59-73$ & $p<0.01$ \\
\hline 2 & 0.4 & $152 \pm 4$ & $131-175$ & $147 \pm 10$ & & \\
\hline 3 & 0.4 & $137 \pm 15$ & $101-194$ & $131 \pm 10$ & $83-199$ & NS \\
\hline 4 & 0.4 & $115 \pm 8$ & $85-134$ & $124 \pm 10$ & $72-194$ & NS \\
\hline 5 & 0.4 & $73 \pm 7$ & $43-103$ & & & \\
\hline 6 & 1.0 & $155 \pm 34$ & $54-307$ & $263 \pm 21$ & $155-400$ & $p<0.02$ \\
\hline 7 & 0.2 & $\begin{array}{l}69 \pm 2 \\
\text { a }\end{array}$ & $58-75$ & $68 \pm 3$ & $49-90$ & NS \\
\hline
\end{tabular}

* See text (pages 594 and 595) for condition.

significantly lower $(p<0.01)$ in the regular tube group: $67 \pm 1 \mathrm{~mm} \mathrm{Hg}$ (range 59 to $73 \mathrm{~mm} \mathrm{Hg}$ ). No significant differences in $\mathrm{O}_{2}$ tensions of the two groups were observed in samples 2, 3, and 4 . However, a gradual decrease was noted in each group, as the operation progressed (Table I). Collapse of the lung on the open side in the Carlens group while the dependent lung was ventilated with $\mathrm{N}_{2} \mathrm{O}: \mathrm{O}_{2}$ (60:40) and 1 per cent halothane decreased the $\mathrm{Pao}_{2}$ significantly $(p<0.01)$, from $115 \pm 8 \mathrm{~mm} \mathrm{Hg}$ to $73 \pm 7 \mathrm{~mm} \mathrm{Hg}$ (Table I, samples 4 and 5). In both groups of patients, changing the inspired gas to $\mathrm{O}_{2}$ and I per cent halothane increased the $\mathrm{PaO}_{2}$ to $155 \pm 35 \mathrm{~mm} \mathrm{Hg}$ in the Carlens group (range 54 to $307 \mathrm{~mm} \mathrm{Hg}$ ) and to 263 $\pm 21 \mathrm{~mm} \mathrm{Hg}$ in the regular tube group (range, 155 to $400 \mathrm{~mm} \mathrm{Hg}$ ). The difference was significant $(p<0.02)$. The calculated mean pulmonary shunting at this point was 25 per cent in the Carlens group (range, 15 to 40 per cent), and a significantly different $(p<0.02) 16$ per cent in the regular tube group (range, 11 to 25 per cent).

While breathing air spontaneously at the end of the operation, patients in the

TABLE II

$\mathrm{PaCO}_{2}, \mathrm{pH}$, and Buffer Base Values During Thoracotomy

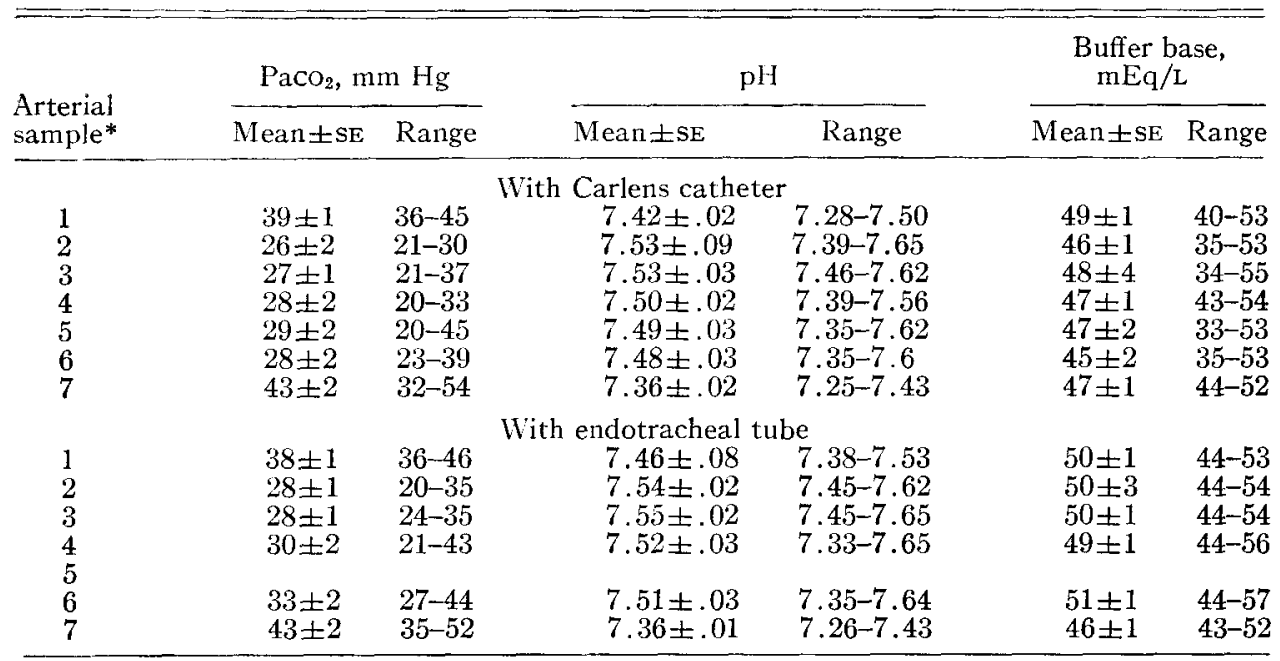

*See text (pages 594 and 595) for condition. 
Carlens group had $\mathrm{PaO}_{2}$ values of $69 \pm 2 \mathrm{~mm} \mathrm{Hg}$ and those in the regular tube group had $\mathrm{PaO}_{2}$ values of $68 \pm 3 \mathrm{~mm} \mathrm{Hg}$. The $\mathrm{Paco}_{2}, \mathrm{pH}$, and buffer base values are given in Table II. The $\mathrm{PaCO}_{2}$ remained normal or below normal throughout the study, except in the final sample, when minimal hypercarbia was demonstrated in some cases.

\section{Comment}

Before the induction of anaesthesia, arterial $\mathrm{O}_{2}$ tensions of the regular endotracheal tube group were significantly lower than those of the Carlens group. The adverse effects of age, ${ }^{5}$ premedication, and pulmonary disease on arterial $\mathrm{O}_{2}$ tensions are well known. ${ }^{2}$ Since similar premedication was used in both groups, it is reasonable to assume that the higher age distribution and perhaps differences in the severity of the pulmonary diseasc were responsible for the lower $\mathrm{O}_{2}$ tensions in the regular endotracheal tube group.

Several factors were responsible for the gradual decrease of $\mathrm{PaO}_{2}$ through sample 4 in both groups (Table I). Craig and associates ${ }^{6}$ have described the relatively frequent occurrence of atelectasis in the dependent lobes during thoracotomy with the patient in the lateral decubitus position. The pulmonary blood flow tends to gravitate to the dependent lung, causing a relative decrease of blood flow to the upper lung. 'A partial or total collapse of the upper lung also may occur from manipulation of the lung by the surgeon. These factors are known to contribute to an alveolar-arterial $\mathrm{O}_{2}$ gradient ${ }^{4}\left(\mathrm{~A}-\mathrm{aDo}_{2}\right)$ because of a maldistribution between vintilation and perfusion.

Elimination of the upper lung from ventilation by clamping the appropriatc lunicn of the Carlens catheter (Table I and Figure 1, sample 5) further decreased the $\mathrm{PaO}_{2}$ significantly. It has been suggested that hypoxaemia in this situation can be avoided by increasing the inspired $\mathrm{O}_{2}$ tension. ${ }^{1}$ The $\mathrm{A}-\mathrm{aDO} 2$ gradients that persist during ventilation with 100 per cent $\mathrm{O}_{2}$ are thought to result principally from atelectasis where unoxygenated blood is shunted past nonventilated alveoli. ${ }^{4}$ Yet, ventilation of patients in the Carlens group with 100 per cent $\mathrm{O}_{2}$ while the upper lung remained collapsed did not provide adequate oxygenation in all instances (Table $\mathrm{I}$, sample 6 ). Three patients had persistently low $\mathrm{O}_{2}$ tensions (54, 59 , and $63 \mathrm{~mm} \mathrm{Hg}$ ); their alveolar ventilation was ample as indicated by the $\mathrm{PaCo}_{2}$.

It might be expected that with the elimination of ventilation in a lung with normal blood flow, up to 50 per cent of the total pulmonary blood flow could shunt through this lung. The mean calculated pulmonary shunt was 25 per cent after collapse of the upper lung in the Carlens group. It is reasonable to assume that this collapse also caused a decrease of blood flow through the same lung, yet the magnitude of the shunt was large enough to be a major cause of hypoxaemia in some patients in this group.

If an $\mathrm{O}_{2}$ tension of $70 \mathrm{~mm} \mathrm{Hg}$ is accepted as the lowest safe level during anaesthesia in patients with normal or only slightly impaired cardiovascular function, ${ }^{1}$ oxygenation of the patients intubated with the regular endotracheal tube was most satisfactory throughout the study. One patient in this group had an $\mathrm{O}_{2}$ tension of $72 \mathrm{~mm} \mathrm{Hg}$ while being ventilated with 40 per cent $\mathrm{O}_{2}$ (Table $\mathrm{I}$, sample 4 ). An increase of the inspired $\mathrm{O}_{2}$ concentration to 100 per cent brought the mean $\mathrm{O}_{2}$ 


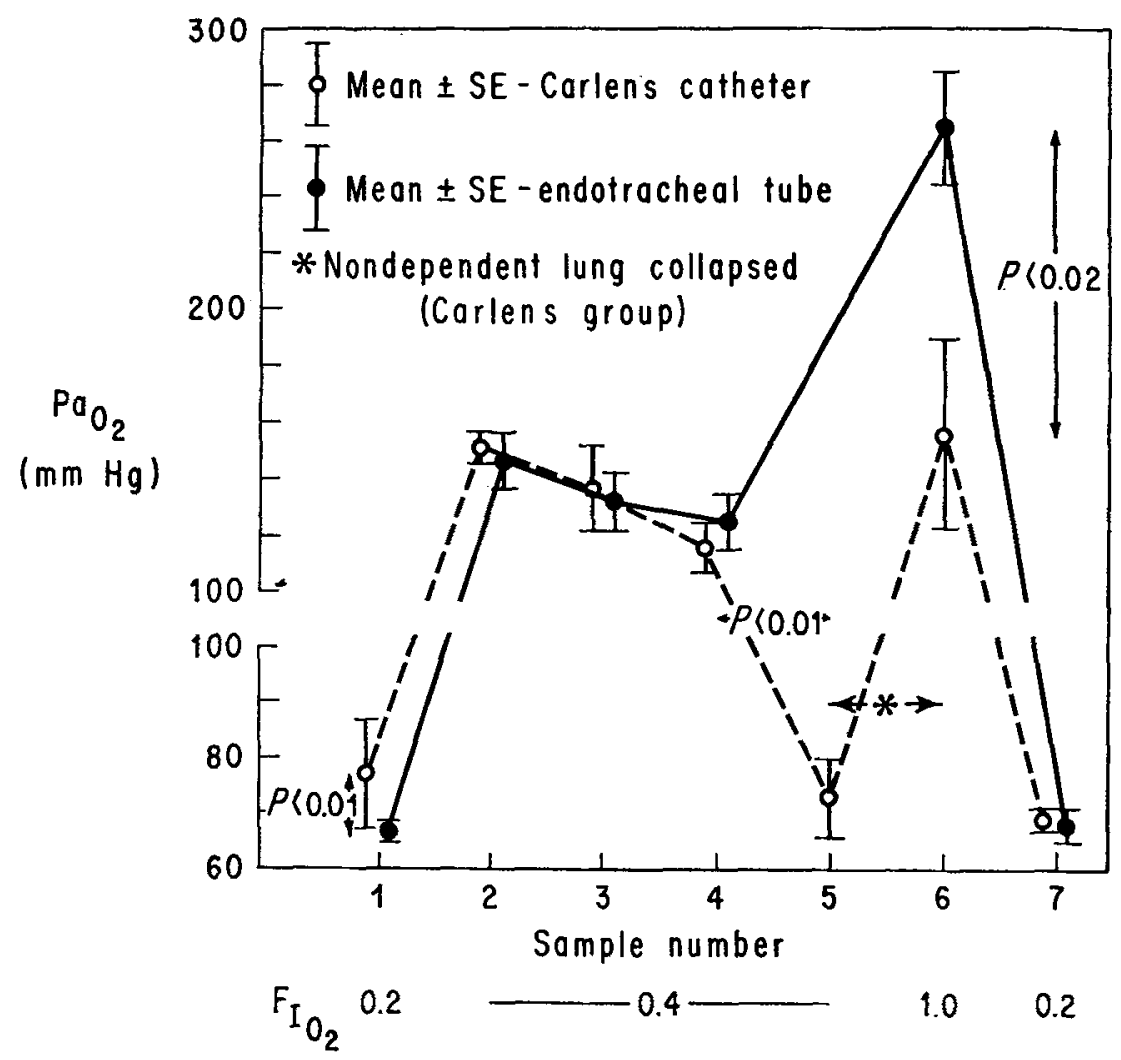

FIGURE 1. Comparison of $\mathrm{PaO}_{2}$ during thoracic surgery with Carlens catheter versus regular endotracheal tube.

tension to $263 \mathrm{~mm} \mathrm{Hg}$ in this group (Figure 1, sample 6). The calculated pulmonary shunting through atelectatic areas was 16 per cent of the total cardiac output, which was significantly less than in the Carlens group. It may be concluded that the lung in the open hemithorax in patients intubated with a regular endotracheal tube does contribute to the oxygenation of blood even if it is partially collapsed. In these patients 100 per cent $\mathrm{O}_{2}$ can provide $\mathrm{O}_{2}$ levels well above the minimal required level. On the other hand, elimination of the lung from the anaesthetic system can result in a large shunt with significant desaturation of the arterial blood. This possibility should be carefully considered when choosing an endotracheal tube, and if the Carlens catheter is used, careful monitoring of the arterial $\mathrm{O}_{2}$ tension is a necessity and the collapsed lung may have to be reinflated and ventilated.

Postoperatively there were no significant differences in the $\mathrm{O}_{2}$ and $\mathrm{CO}_{2}$ tensions between the Carlens group and the regular endotracheal tube group. The minimal increase of $\mathrm{CO}_{2}$ and decreased $\mathrm{O}_{2}$ tensions were indicative of alveolar hypoventilation and venous admixture. This corresponded well with findings in previous studies. ${ }^{1}$ The need for an increased inspired $\mathrm{O}_{2}$ concentration in the immediate 
postoperative period is obvious, and in rare cases assisted ventilation may be necessary.

\section{SUMMARY}

Blood gases and pulmonary shunting were studied in 22 patients undergoing thoracic surgery. Eleven patients were intubated with a Carlens catheter and 11 with a regular endotracheal tube. A large degree of pulmonary shunting with corresponding hypoxaemia developed during the collapse of the upper lung in the open hemithorax in the Carlens catheter group. Ventilation with 100 per cent oxygen was not successful in correcting the hypoxaemia in these patients.

Patients with a regular endotracheal tube maintained satisfactory levels of $\mathrm{O}_{2}$ tensions throughout the study while breathing 100 per cent $\mathrm{O}_{2}$, which indicated that the partly collapsed upper lung contributed to ventilation and oxygenation of the patients during surgical procedures.

\section{RÉSUMÉ}

Sur 22 malades soumis à de la chirurgie thoracique, nous avons intubé onze malades avec un tube Carlens et les onze autres avec un tube trachéal ordinaire. Chez les malades intubés avec le Carlens, il s'est installé un shunting pulmonaire avec hypoxhémie durant le collapsus du poumon du côté où travaillait l'équipe chirurgicale. Une ventilation avec 100 per cent d'oxygène n'a pas réussi à corriger cette hypoxhémie. Les malades de l'autre groupe ont conservé des tensions d'oxygène artérielles satisfaisantes lorsqu'ils respiraient une atmosphère à 100 pour cent d'oxygène; cela nous démontre que le poumon supérieur, quoique partiellement collabé, participe à la ventilation et à l'oxygénation au cours de la chirurgie.

\section{REFERENCES}

1. Lunding, M. \& Fernandes, A. Arterial Oxygen Tension and Acid-Base Status During Thoracic Anesthesia: With Special Reference to the Effect of Total Collapse of One Lung as Obtained by Using Double-Lumen Tubes. Acta Anaesthe. Scand., 11: 43 (1967).

2. Tarhan, S. \& Lundorg, R. O. Blood Gas and $\mathrm{pH}$ Studies During Use of the Carlens Catheter. Canad. Anaesth. Soc. J., 15: 458 (1968).

3. Singer, R. B. \& Hastings, A. B. An Improved Clinical Method for the Estimation of Disturbances of Acid-Base Balance of Human Blood. Medicine (Balt), 27: 223 (1948).

4. Laver, M. B. \& Seifen, A. Measurement of Blood Oxygen Tension in Anesthesia. Anesthesiology, 26:73 (1965):

5. Raine, J. M. \& Bishor, J. M. A-a Difference in $\mathrm{O}_{2}$ Tension and Physiological Dead Space in Normal Man. J. Appl. Physiol., 18: 284 (1963).

6. Craig, J. O. C.; Bromley, L. L.; \& Williams, R. Thoracotomy and the Contralateral Lung: A Study of the Changes Occurring in the Dependent and Contralateral Lung During and After Thoracotomy in Lateral Decubitus. Thorax, 17: 9 (1962).

7. Svanberg, L. Influence of Posture on the Lung Volumes, Ventilation and Circulation in Normals: A Spirometric-Bronchospirometric Investigation. Scand. J. Clin. Lab. Invest., 9 Suppl. 25: 1 ( 1957 ). 